\title{
Implication of $\alpha 4$ phosphoprotein and the rapamycin-sensitive mammalian target-of-rapamycin pathway in prolactin receptor signalling
}

\author{
R T M Boudreau ${ }^{1}$, S M Sangster ${ }^{1}$, L M Johnson ${ }^{1}$, S Dauphinee ${ }^{1}$, \\ A W Li ${ }^{2}$ and C K L Too ${ }^{1,3}$ \\ ${ }^{1}$ Department of Biochemistry and Molecular Biology, Faculty of Medicine, Sir Charles Tupper Medical Building, Dalhousie University, Halifax, \\ Nova Scotia B3H 4H7, Canada \\ ${ }^{2}$ Division of Endocrinology and Metabolism, Department of Medicine, Faculty of Medicine, Dalhousie University, Halifax, Nova Scotia B3H 4H7, Canada \\ ${ }^{3}$ Department of Obstetrics and Gynecology, Faculty of Medicine, Dalhousie University, Halifax, Nova Scotia B3H 4H7, Canada \\ (Requests for offprints should be addressed to C K L Too; Email: ctoo@is.dal.ca)
}

\begin{abstract}
A prolactin (PRL)-responsive $3{ }^{\prime}$-end cDNA encoding rat a4 phosphoprotein was previously isolated from a rat lymphoma cDNA library. Rat $\alpha 4$ is a homologue of yeast Tap42 and is a component of the mammalian target-ofrapamycin (mTOR) signalling pathway that stimulates translation initiation and G1 progression in response to nutrients and growth factors. In the present study, the full-length rat $\alpha 4$ cDNA was obtained by $5^{\prime}$-RACE and the $1023 \mathrm{bp}$ open reading frame predicted a 340 amino acid protein of $39 \cdot 1 \mathrm{kDa}$. The $\alpha 4 \mathrm{mRNA}$ was expressed in quiescent PRL-dependent $\mathrm{Nb} 2$ lymphoma cells deprived of PRL for up to $72 \mathrm{~h}$ but expression was downregulated within $4 \mathrm{~h}$ of PRL treatment. In contrast, PRLindependent $\mathrm{Nb} 2-\mathrm{Sp}$ cells showed constitutive expression of $\alpha 4$ that was not affected by PRL. Western analysis of $\mathrm{Nb} 2$ cell lysates or of V5-tagged- $\alpha 4$ expressed in COS-1 cells detected a single immunoreactive band of $\sim 45 \mathrm{kDa}$. Enzymatic deglycosylation of affinity-purified $45 \mathrm{kDa} \alpha 4$ yielded the predicted $39 \mathrm{kDa}$ protein. Phosphorylation of
\end{abstract}

$\mathrm{Nb} 2 \alpha 4$ was induced by PRL or 2-O-tetradecanoylphorbol-13-acetate (TPA) and further enhanced by a combination of PRL and TPA. The Nb2 $\alpha 4$ associated with the catalytic subunit of protein phosphatase $2 \mathrm{~A}$ and localized predominantly in $\mathrm{Nb} 2$ nuclear fractions with trace amounts in the cytosol. The immunosuppressant drug rapamycin inhibited proliferation of $\mathrm{Nb} 2$ cells in response to PRL or interleukin-2, but had no effect on $\mathrm{Nb} 2-\mathrm{Sp}$ cells. Furthermore, transient overexpression of $\alpha 4$ in COS-1 cells inhibited PRL stimulation of the immediate-early gene interferon regulatory factor- 1 promoter activity. Therefore, PRL downregulation of $\alpha 4$ expression and/or PRL-inducible phosphorylation of $\alpha 4$ may be necessary for PRL receptor (PRLr) signalling to the interferon regulatory factor- 1 promoter in the $\mathrm{Nb} 2$ cells and, furthermore, implicates cross-talk between the mTOR and PRLr signalling cascades during Nb2 cell mitogenesis.

Journal of Endocrinology (2002) 173, 493-506

\section{Introduction}

Prolactin receptor (PRLr) signal transduction is mediated by the activation of several receptor-associated kinase cascades and results in the transmission of a mitogenic and/or lactogenic signal in target cells (Yu-Lee 1997, Clevenger et al. 1998). PRLr-associated and PRLactivated Jak2 tyrosine kinase recruits and phosphorylates members of the signal transducer and activator of transcription (Stat) family of latent cytoplasmic transcription factors (Campbell et al. 1994, Rui et al. 1994). Stat binding to the interferon $\gamma$-activated sequence mediates the mitogenic signalling of PRL to the immediate-early gene interferon regulatory factor-1 (IRF-1) in the rat PRLdependent Nb2 lymphoma cells (Stevens et al. 1995,
Wang et al. 1997). PRLr signal transduction also involves three other receptor-associated molecules, p59 fyn tyrosine kinase (Clevenger \& Medaglia 1994), Raf-1 serine/ threonine kinase (Clevenger et al. 1994) and 2'5 'oligoadenylate synthetase (OAS) (McAveney et al. 2000). PRL activation of the p59 fyn/Sos/Vav/Raf-1/ MAP kinase cascade has been reported to stimulate $\mathrm{Nb} 2$ cell proliferation (Clevenger \& Medaglia 1994, Clevenger et al. 1994) whereas OAS reduced PRL induction of IRF-1 promoter activity (McAveney et al. 2000). PRL has also been shown to stimulate tyrosine phosphorylation of cytoplasmic protein tyrosine phosphatase (PTP1D), and formation of a PRLr-Jak2-PTP1D complex was critical for transmission of a lactogenic signal (Ali et al. 1996). PRLr activation also resulted in PRL internalization 
(Vincent et al. 1997) whereby PRL is transported across the endoplasmic reticulum and nuclear envelope in a process termed nuclear retrotranslocation (Clevenger et al. 1990, Rao et al. 1995). The peptidylprolyl isomerase cyclophilin B has been revealed as an important chaperone facilitating nuclear retrotransport of PRL (Rycyzyn et al. 2000).

In our studies on differential gene expresssion in the PRL-dependent Nb2 and the PRL-independent Nb2-Sp rat lymphoma cell lines, we have previously identified, by differential display and screening of an $\mathrm{Nb} 2-\mathrm{Sp}$ cDNA library, a number of genes which are differentially expressed in $\mathrm{Nb} 2$ cells (with or without acute PRL treatment for $3 \mathrm{~h}$ ) versus $\mathrm{Nb} 2-\mathrm{Sp}$ cells (Too 1997, Johnson \& Too 2001, Too et al. 2001). One of these was a PRL-responsive partial cDNA encoding the rat homologue of $\alpha 4$ phosphoprotein (Too 1997). The action of $\alpha 4$ in PRL-regulated $\mathrm{Nb} 2$ cell proliferation is not known. The murine $\alpha 4$ cDNA (Inui et al. 1995) and human $\alpha 4$ (IGBP1) gene (Onda et al. 1997) have also been cloned. Murine $\alpha 4$ was originally identified in murine lymphoid cell lines as a $52 \mathrm{kDa}$ protein (p52) that co-precipitated with the Ig receptor (IgR)-related $\mathrm{MB}-1$ protein (Kuwahara et al. 1994). A novel murine $\alpha 4-\mathrm{b}$ genomic clone has been shown to be selectively expressed in the testis and in the brain (Maeda et al. 1999).

Mammalian $\alpha 4$ is a homologue of yeast Tap42, an essential component of the target-of-rapamycin (TOR) kinase signalling pathway controlling translational initiation and survival in yeast cells (Di Como \& Arndt 1996). Yeast Tap42 associates with the serine/threonine protein phosphatases, PP2A and Sit4. The mammalian TOR (mTOR) pathway is conserved in mammalian cells. Mouse and human $\alpha 4$ also associate with $\mathrm{PP} 2 \mathrm{~A}$ and/or the PP2A isoforms, PP4 and PP6 (Chen et al. 1998, Inui et al. 1998). The TOR/mTOR proteins belong to a novel family of phosphatidylinositol kinase-related kinases, which include mammalian phosphatidylinositol 3-kinase. The mTOR pathway responds to mitogens and nutrients to stimulate translation initiation and cell growth via activation of p70S6 kinase (p70S6K) and inactivation of the translational repressor 4E-BP1 (or PHAS-1), as well as through effects mediated by the $\alpha 4-\mathrm{PP} 2 \mathrm{~A}$ interaction (Thomas \& Hall 1997, Cutler et al. 1999). mTOR phosphorylation and activation of p70S6K leads to activation of ribosomal protein S6 to promote translation of 5 '-terminal oligopyrimidine tract mRNAs, ribosome biogenesis and increased capacity of the translational machinery (Jiang \& Broach 1999). mTOR phosphorylation and inactivation of 4E-BP1 alleviates inhibition of the eukaryotic translational initiation factor $4 \mathrm{E}$ to enhance the translation of all mRNAs (Thomas \& Hall 1997). The $\alpha 4-\mathrm{PP} 2 \mathrm{~A}$ interaction is believed to stimulate the initiation of translation, through effects on p70S6K and/or 4E-BP1. The augmentation of global translation results in cell growth (in size) and proliferation (progression into G1). It is believed that by utilizing the mTOR pathway to sense nutrients and mitogenic signals, mammalian cells may co-ordinate responses to mitogens relative to the nutrients available to carry out the response (Cutler et al. 1999). The mTOR pathway is sensitive to the anti-fungal and immunosuppressive drugs, rapamycin and FK506, which bind to a cytosolic family of FK506-binding proteins (FKBPs) with peptidylprolyl isomerase activities (Sehgal 1998). The rapamycin-FKBP complex thus formed is an active intracellular toxin which diminishes the association of $\alpha 4$ (or Tap42) with PP2A, thereby inhibiting protein synthesis and arresting cells in G1 (Di Como \& Arndt 1996, Thomas \& Hall 1997). Indeed, rapamycin is a potent inhibitor of interleukin-2 (IL-2)-induced T-cell proliferation (Morice et al. 1993a,b). Mutations in Tap42 have been reported to confer rapamycin resistance in yeast cells (Di Como \& Arndt 1996).

The present study showed that PRL-responsive rat $\alpha 4$ is a glycophosphoprotein which also binds to PP2Ac. We also showed that rapamycin or transient overexpression of $\alpha 4$ inhibited PRL-stimulated cell proliferation and IRF-1 promoter activity, suggesting cross-talk between the mTOR and PRLr signalling cascades.

\section{Materials and Methods}

\section{Hormones and drugs}

Human PRL was a generous gift from Dr R P C Shiu (Department of Physiology, University of Manitoba, Manitoba, Canada). Human recombinant IL-2 was from Upstate Biotechnology (Lake Placid, NY, USA). Rapamycin, 12-O-tetradecanoyl-phorbol-13-acetate (TPA) and biologically inactive isophorbol, $4 \alpha, 9 \alpha, 12 \beta, 13 \alpha, 20-$ pentahydroxytiglia-1,6-dien-3-one (4 $\alpha$-PHR) were from Sigma RBI (St Louis, MO, USA).

\section{Antibodies and a4-antiserum}

The commercial sources of antibodies used were as follows: mouse anti-Stat1 $\alpha$ p91 (C-111), rabbit antitranscription factor TFIIB (SI-1), goat anti-glucokinase $(\mathrm{C}-20)$ and the horse radish peroxidase (HRP)conjugated-goat anti-mouse $\operatorname{IgG}$ or -donkey anti-goat $\operatorname{IgG}$ (Santa Cruz Biotechnology Inc., Santa Cruz, CA, USA); donkey anti-rabbit IgG-HRP conjugate (Amersham Pharmacia Biotechnology, Baie d'Urfe, Quebec, Canada); rabbit anti-mTOR (Upstate Biotechnology); mouse antiPP2A catalytic subunit (PP2Ac) (Transduction Laboratories, Lexington, KY, USA), anti-phosphoserine (Sigma RBI); and anti-PRLr (Affinity Biotech. Inc, Golden, CO, USA). Based on the deduced rat $\alpha 4$ protein, anti-rat $\alpha 4$ antiserum was raised against a synthetic peptide conjugated to keyhole limpet haemocyanine (KLH) (KLHEWDDWKDATHPRGYGNRQNMG; see Fig. 1), to 
raise rabbit polyclonal antibodies to rat $\alpha 4$ (Research Genetics, Huntsville, AL, USA). The preimmune serum and antiserum were purified on protein A-Sepharose columns prior to use and yielded 3.2 and $5.2 \mathrm{mg}$ protein $/ \mathrm{ml}$ respectively.

\section{Cell culture}

Suspension cultures of the rat $\mathrm{Nb} 2-11 \mathrm{C}(\mathrm{Nb} 2)$ lymphoma cell line were maintained in Fischer's medium for leukaemic cells containing 10\% fetal bovine serum (FBS) as a source of lactogens and 10\% lactogen-free horse serum (HS) as previously described (Too et al. 1987). Nb2 cells were growth-arrested at a cell density of $\sim 1.0 \times 10^{6}$ cells $/ \mathrm{ml}$ in medium containing 10\% HS alone for 18-24 h. For bioassays, quiescent cells at $0 \cdot 2 \times 10^{6}$ cells $/ \mathrm{ml}$ in $10 \%$ HS medium were treated with PRL (10 ng/ml), IL-2 (30 $\mathrm{U} / \mathrm{ml}$ ) or rapamycin and cells were counted on day 3 with a Coulter counter. For expression studies, quiescent cells at $0.6 \times 10^{6}$ cells $/ \mathrm{ml}$ were treated with PRL for the indicated times whereas controls were untreated. $\mathrm{Nb} 2-\mathrm{Sp}$ cells also express receptors for PRL but, unlike $\mathrm{Nb} 2$ cells, are PRL-independent and were maintained in 10\% HS medium; cells at late-log phase were similarly reduced to a cell density of $0.6 \times 10^{6}$ cells $/ \mathrm{ml}$ (for expression studies) or $0.2 \times 10^{6}$ cells $/ \mathrm{ml}$ (for 3-day bioassays) prior to hormone or drug treatment. COS-1 cells were maintained in Dulbecco's modified Eagle's medium (DMEM) containing 10\% FBS.

\section{Rapid amplification of $5^{\prime}-c D N A$ ends $\left(5^{\prime}-R A C E\right)$}

In an earlier study, the incomplete rat $\alpha 43^{\prime}$-end cDNA (1220 bp) was identified by differential display and cloned from an Nb2-Sp cDNA library (Too 1997). In the present study, the $5^{\prime}$-end sequence was completed by 5 '-RACE (Marathon cDNA Amplification Kit; CLONTECH Laboratories, Inc., Palo Alto, CA, USA) using the same $\mathrm{Nb} 2-\mathrm{Sp}$ cDNA library. A single base mutation was identified in the partial rat $\alpha 4$ cDNA clone that was reported earlier and the corrected sequence of the fulllength rat $\alpha 4$ cDNA has been updated in GenBank (accession number AF000577).

\section{Generation of full-length a 4 cDNA (pcDNA3·1-a4-V5 clone)}

The full-length $\alpha 4$ cDNA, with engineered 5' Kpn1 and 3'Apa1 sites, was obtained by two rounds of PCR of the $\mathrm{Nb} 2-\mathrm{Sp}$ cDNA library with the primers $5^{\prime}$-atggcagcg tctgaagaagagttactgctg- $3^{\prime}$ and $5^{\prime}$-caaggggccctttgacactatca aatgc- $3^{\prime}$, and $5^{\prime}$-gcttggtaccaagatggcagcgtctgaag- $3^{\prime}$ and $5^{\prime}-$ caaggggccctttgacactatcaaatgc- $3^{\prime}$ respectively. The PCR product from the second round of PCR was restriction digested with Kpn1 and Apa1, then ligated into the Kpn1/Apa1 multiple cloning sites of the pcDNA3.1 expression vector which has a $3^{\prime}$-end V5 epitope (Invitrogen Corporation, Carlsbad, CA, USA).

\section{Northern analysis and semi-quantitative RT-PCR}

DNA-free total RNAs were extracted from $\mathrm{Nb} 2$ cells and used for Northern or RT-PCR analysis. The $\alpha 4$ mRNAspecific primers $5^{\prime}$-gagttactgctgccgcggettccggagc- $3^{\prime}$ and $5^{\prime}$-cgagcccgctgcaaatgatctagacgc- $3^{\prime}$ gave a $304 \mathrm{bp}$ product. The 18S primers used ( $315 \mathrm{bp}$ product) were from the QuantumRNA 18S Internal Standards Kit (Ambion Inc., Austin, TX, USA). All PCR products were obtained within the linear range of the reaction.

\section{Glutathione S-transferase (GST)-a4-V5 fusion protein}

$B a m H 1$ and $E c o R 1$ restriction sites were incorporated into the pcDNA3-1- $\alpha 4-\mathrm{V} 5$ clone by PCR using primers $5^{\prime}$-gcttggatccaagatggcagcgtctgaag- $3^{\prime}$ and $5^{\prime}$-gaccggaattcg tagaatcgagaccgag- $3^{\prime}$ to generate a $1204 \mathrm{bp}$ product. This was cloned in-frame into the BamH1 and EcoR1 sites of pGEX-2T GST gene fusion vector (Amersham). Transformation of competent $E$. coli with pGEX2T- $\alpha 4$, induction of GST- $\alpha 4-\mathrm{V} 5$ expression with $100 \mathrm{mM}$ isopropyl-1-thio- $\beta$-D-galactoside (IPTG) and analysis of transformants were performed as described (Ausubel et al. 1994). For GST-fusion protein pull-down assays, total cell lysates were incubated with GST- $\alpha 4$ fusion proteins conjugated to glutathione-Sepharose beads. Protein complexes were washed, resolved by SDS-PAGE and transferred to nitrocellulose membranes for immunoblotting.

\section{Subcellular fractionation, immunoprecipitation, affinity purification and Western analysis}

Subcellular fractionation was performed as previously described (Dodd et al. 2000) to obtain nuclear $(800 \mathrm{~g}$ pellet, $5 \mathrm{~min}$ ), microsomal (100 $000 \mathrm{~g}$ pellet, $60 \mathrm{~min})$ and cytosolic (100 $000 \boldsymbol{g}$ supernatant) fractions. Proteins (8$20 \mu \mathrm{g} /$ lane), representing about $4 \%$ of total protein from each fraction, were electrophoresed on 10\% SDS-PAGE gels. Immunoprecipitation and Western analysis were performed as described (Dodd et al. 2000). Nb2 a4 was affinity purified using $\alpha 4$-antibodies bound to Plus Immobilized Protein G (Pierce, Rockford, IL, USA). Affinity-purified $\alpha 4$ was deglycosylated with an Enzymatic Deglycosylation Kit (BioRad Laboratories Ltd, Mississauga, Ontario, Canada) following the manufacturer's instructions.

\section{$\left.{ }^{32} \mathrm{P}\right]$-orthophosphate labelling and phosphoamino acid analysis}

$\mathrm{Nb} 2$ cells were labelled with $\left[{ }^{32} \mathrm{P}\right]$-orthophosphate (TPA $\pm \mathrm{PRL}$ ) as described (Rayhel et al. 1988, Fulton et al. 1999), with modifications. Briefly, quiescent $\mathrm{Nb} 2$ cells $\left(10 \times 10^{6}\right.$ per treatment) were pelleted at $200 \boldsymbol{g}$ for 
$5 \mathrm{~min}$ at room temperature, washed twice with phosphate-free RPMI 1640 (Life Technologies, Burlington, Ontario, Canada) and resuspended in $5 \mathrm{ml}$ of the same medium for a $1-\mathrm{h}$ incubation at $37^{\circ} \mathrm{C}$. Cells were incubated with $\left[{ }^{32} \mathrm{P}\right]$-orthophosphate $(0 \cdot 1 \mathrm{mCi} / \mathrm{ml})$ for $70 \mathrm{~min}$ at $37^{\circ} \mathrm{C}$. TPA $(20-80 \mathrm{nM}) \pm \operatorname{PRL}(10 \mathrm{ng} / \mathrm{ml})$ was added and inactive phorbol $4 \alpha$-PHR ( $40 \mathrm{nM}$ ) was used as negative control. After $20 \mathrm{~min}$ at $37{ }^{\circ} \mathrm{C}$, the cells were pelleted at $200 \mathrm{~g}$ (5 min), washed twice with icecold phosphate-buffered saline (PBS) containing $10 \mu \mathrm{M}$ $\mathrm{Na}_{3} \mathrm{VO}_{4}, 10 \mathrm{mM} \mathrm{NaF}, 10 \mathrm{mM} \mathrm{Na} \mathrm{P}_{2} \mathrm{O}_{7}$ and $440 \mu \mathrm{M}$ EDTA. Cell pellets were resuspended in $0.5 \mathrm{ml}$ RIPA buffer and total cell lysates were used for immunoprecipitation with anti- $\alpha 4$ antibodies. For phosphoamino analysis, immunoprecipitated $\left[{ }^{32} \mathrm{P}\right]$-labelled proteins were resolved by SDS-PAGE, excised from the gel, washed twice with $1 \mathrm{ml} \mathrm{25 \%}$ isopropanol (v/v)-10\% methanol (v/v) and minced in 150-200 $\mu \mathrm{l} 50 \mathrm{mM}$ ammonium bicarbonate. Trypsin-L-[1-tosylamido-2-phenyl] ethyl chloromethyl ketone (10 $\mu \mathrm{l}$ of a $10 \mathrm{mg} / \mathrm{ml}$ stock) was added to each tube for an overnight digestion at $37^{\circ} \mathrm{C}$. Insoluble material was precipitated and the supernatants were lyophilized and redissolved in $50 \mu \mathrm{l} 6 \mathrm{M} \mathrm{HCl}$ for hydrolysis at $110{ }^{\circ} \mathrm{C}$ for $90 \mathrm{~min}$. Dried samples and phosphoamino acid standards were dissolved in $10 \mu \mathrm{l}$ distilled water for thin-layer chromatography in isopropanol: $\mathrm{H}_{2} \mathrm{O}: \mathrm{HCl}(65: 8 \cdot 4: 6 \cdot 6)$. Samples were visualized with ninhydrin $(0.5 \%$ in acetone $(\mathrm{w} / \mathrm{v}))$ or by autoradiography.

\section{Chloramphenicol acetyltransferase (CAT) assay}

Transient transfection of COS-1 cells and CAT assays were performed as described (McAveney et al. 2000). CAT activity was determined by the fluor-diffusion method (Neumann et al. 1987) with slight modifications. Briefly, COS-1 cells $\left(2 \times 10^{5}\right.$ per well in a 6-well dish) were cultured overnight in DMEM-10\% FBS and then rinsed with DMEM. Transient transfection was performed with LipofectAMINE-DNA mixture containing $5 \mu \mathrm{l}$ LipofectAMINE (Life Technologies, Grand Island, NY, USA), $1 \mu \mathrm{g}$ pECE-Nb2-PRLr, $0 \cdot 2 \mu \mathrm{g} 1.7 \mathrm{~kb}$ IRF-1CAT, $1 \mu \mathrm{g}$ pcDNA3-Stat $1 \alpha$ and $1 \mu \mathrm{g}$ pcDNA3- $\alpha 4$ or $1 \mu \mathrm{g}$ pcDNA3-antisense $\alpha 4$ or $1 \mu \mathrm{g}$ control pcDNA3·1, in a total volume of $1 \mathrm{ml}$ DMEM. The antisense pcDNA3- $\alpha 4$ construct was made by restriction digestion of pcDNA3-1- $\alpha 4-\mathrm{V} 5$ to obtain a $252 \mathrm{bp} K p n 1 / K p n 1$ insert containing the initiation factor ATG and a $6.5 \mathrm{~kb}$ DNA fragment; these were religated and constructs with sense or antisense orientations were determined by restriction digestion. After $5 \mathrm{~h}$ at $37^{\circ} \mathrm{C}$, the LipofectAMINEDNA mixture was aspirated and replaced with DMEM-1\% HS for 18-24 h, then washed twice with PBS and harvested in PBS containing $1 \mathrm{M}$ EDTA. The cells were pelleted by centrifugation at $800 \mathrm{~g}$ for $5 \mathrm{~min}$ at $4{ }^{\circ} \mathrm{C}$ followed by resuspension in $100 \mu 1100 \mathrm{mM}$ Tris, $\mathrm{pH}$ $7 \cdot 8$ containing $0 \cdot 1 \%$ Triton $\mathrm{X}-100$. After $10-15 \mathrm{~min}$ on ice, nuclei and cell debris were pelleted by centrifugation $(800 \mathrm{~g}, 15 \mathrm{~min})$ and the supernatant recovered. Aliquots were used for BioRad protein assay. To assay for CAT activity, equal amounts of protein extracts were mixed with $100 \mathrm{mM}$ Tris, $\mathrm{pH} 7 \cdot 8$ containing $0 \cdot 1 \%$ Triton $\mathrm{X}-100$ in a total volume of $200 \mu \mathrm{l}$ and placed in $7 \mathrm{ml}$ scintillation vials. The vials were heated at $70{ }^{\circ} \mathrm{C}$ for $10 \mathrm{~min}$ to inactivate heat-labile cellular acetyltransferases and then cooled at room temperature for $10 \mathrm{~min}$ before the addition of $75 \mu \mathrm{l}$ reaction cocktail containing $0.5 \mathrm{M}$ Tris $-\mathrm{HCl}, \mathrm{pH}$ $7 \cdot 8, \quad 0.2 \mathrm{mCi}\left[{ }^{3} \mathrm{H}\right]$-acetyl CoenzymeA and $1.75 \mathrm{mM}$ chloramphenicol. ScintiLene SX2-4 (Fisher Scientific, Nepean, Ontario, Canada) was pre-warmed to $37^{\circ} \mathrm{C}$ and $3 \mathrm{ml}$ was carefully layered over the aqueous samples. The vials were capped and samples were counted for five cycles for at least $1 \mathrm{~min} / \mathrm{sample}$ with no interruptions. The data were analyzed by regression analysis and expressed as c.p.m./ $/$ g protein.

\section{Statistical analysis}

Analysis of variance and Scheffe's F-test were performed using Abacus Concepts, Statview (Abacus Concepts, Inc., Berkeley, CA, USA; 1992).

\section{Results}

\section{Full-length sequence of rat a $4 \mathrm{cDNA}$ by $5^{\prime}$-RACE}

A partial rat $\alpha 43^{\prime}$-end cDNA was identified as PRLresponsive in the Nb2 cells (Too 1997). The full-length rat $\alpha 4$ cDNA (1239 bp; GenBank accession number AF000577) was obtained by $5^{\prime}$-RACE and it has an open reading frame of 1023 bases encoding a 340 residue protein with a predicted molecular weight (MW) of $39 \cdot 1 \mathrm{kDa}$. The deduced rat $\alpha 4$ protein has significant sequence identity with $\alpha 4$ and $\alpha 4$-related molecules of mouse ( $\alpha 4,97 \%$; $\alpha 4-b, 85 \%)$, human ( $\alpha 4 /$ IGBP1, 95\%) and yeast (Tap42, 48\%) (Fig. 1; see also Maeda et al. 1999). Like other $\alpha 4$ molecules, rat $\alpha 4$ has multiple potential phosphorylation sites for protein kinase $\mathrm{C}$ (PKC) or casein kinase 2, sites for $\mathrm{N}$-linked glycosylation and potential myristylation as well as a potential SH3-binding motif.

\section{a $4 \mathrm{mRNA}$ is widely expressed in rat and human tissues or cell lines}

The $\alpha 4$ transcript was expressed in quiescent $\mathrm{Nb} 2$ cells deprived of PRL for $20 \mathrm{~h}$ (Fig. 2A and B, right-hand panel; $0 \mathrm{~h}$ time) but this level of expression decreased within $4 \mathrm{~h}$ of PRL treatment as shown by Northern (Fig. 2A, $1.4 \mathrm{~kb}$ mRNA) or RT-PCR analyses (Fig. 2B, $304 \mathrm{bp}$ product). $\mathrm{Nb} 2$ expression of $\alpha 4$ during PRL deprivation was maintained for as long as $72 \mathrm{~h}$ (Fig. 2B, left-hand panel). The PRL-independent $\mathrm{Nb} 2-\mathrm{Sp}$ cells have receptors for PRL, but PRL had no detectable effect on $\alpha 4$ mRNA levels in these cells (Fig. 2C). 


\begin{tabular}{|c|c|c|c|c|c|c|c|c|}
\hline rod & IAASEEE¿LL & RLPELFETS & KKLLEELEVA & TEPTGSRTIQ & KVSKGLELL & GMI SQI & EDLE & 70 \\
\hline $\mathrm{m} \alpha 4$ & [AASEDELLL & RLPELFETS & KKLLEDVEVA & TEPTGSRTIQ & DKVSKGLELL & GMLSQL & DLESRNEDLE & 70 \\
\hline $\mathrm{m} \alpha 4-\mathrm{b}$ & IASFTEEMQK & KLRELIETG & IQLLEEVEAA & TQPTGSKPIQ & KVREALKLL & EKASDML SQL & DLFSRNEDWE & 70 \\
\hline$\alpha 4$ & IAA-EDELQI & RLPELFETG & RQLLDEVEVA & TEPAGSRIVQ & KVFKGLDLL & $Q L$ & NEDLE & 69 \\
\hline $\operatorname{Tan} 42$ & ASVTEQEN- & DIISLYSTK & ---LEHTSLR & GLL & ISTIK--KLL & RL & ETID & 63 \\
\hline & YL & VPALQGALT & MKQ $\cdots-\cdots \bar{V}$ & - SKRLDH & $\mathrm{IH}$ & $\mathrm{HV}$ & IKN & \\
\hline $\mathrm{m} \alpha 4$ & IASTDLKYL & VPALQGALT & $M K Q------V$ & -- SKRLDH & $\mathrm{FVH}$ & $\mathrm{ZHV}$ & QTKT & \\
\hline$a 4-b$ & EIASADLKYL & MLPALKGALT & LKL $-----V$ & GS--SKRLGL & $\pm Q D$ & $\mathrm{HV}$ & WAQS & \\
\hline T & EIASTDLKYL & VPAFQGALT & MKQ $\cdots----V$ & NP- - SKRLDH & IQ & $\mathrm{HV}$ & TTMN & \\
\hline Ton & DVSTASI & AVDYYLGLLI & SRRQSNDSDV & AQRQSMKLIY & IN & $\mathrm{KKL}$ & EKLG & \\
\hline$x 4$ & $\mathrm{~S}$ & - & VASQR & $\mathrm{KQK}$ & $\mathrm{AL}$ & $\mathrm{AD}$ & REY & 193 \\
\hline 1 & $S S$ & -- & $-\mathrm{NL}$ & $\mathrm{KQK}$ & $\mathrm{AL}$ & $\mathrm{AD}$ & REY & \\
\hline$\alpha^{4}-\mathrm{b}$ & $T$ & ---- & -NLVAMASQR & QTKIQRYKQK & KAV & $A D$ & DER- & \\
\hline & $S$ & & $-S L V$ & QAKIQRYKQK & $A M$ & $A D$ & VREY & \\
\hline & NFKL & $Q P K N N$ & KDLSGAQLKR & KEKIEIFQRN & KEISTY & DED & LREL & \\
\hline 4 & $1+1$ & $D$ & QEI- & $\mathrm{D}--$ & & PEL & $\mathrm{AKV}$ & \\
\hline 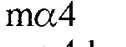 & HLLHL & ELESID & QEI-- KILK & E--KDSPREE & ER & PEI & $\mathrm{AKV}$ & \\
\hline & YLEQL & ISLDE & QEI--.-EIIR & $E--R D S L G E T$ & QER & PP- & QAKV & \\
\hline & YLLHLQRWID & ISLEEIESID & QEI---KIIR & E--RDSSREA & $Q E R$ & $\mathrm{PP}--$ & ZAKV & \\
\hline & YLMRLHH--- & FSLDTINNIE & QNLFECEMLS & NFLK & RKE & GFT & KPL & \\
\hline & PSLAT & MTVSDWYEQH & QKYGA----- & ----LPDRGI & FQR & $2 \mathrm{EQ}$ & - -EEK & \\
\hline & FGTGYPSLAT & MTVSDWYEQH & QKYGV----- & $\ldots-$ LPDRGI & $\mathrm{AKP}$ & $\mathrm{AAQ}$ & $--E E K$ & \\
\hline & FGTGYPSLAT & MTVSDWYEQR & QKNEV----- & - SPTLQEAEK & FTV & LEQ & $---D E N$ & \\
\hline & FGAGYPSLPT & MTVSDWYEQH & RKYGA $\cdots$ & ---- LPDQGI & FRK & QEEQEE & KEEED--DEQ & \\
\hline & IDKKGQVLRN & FTLVDKRQQL & QQKVRGYGQY & GPTMSVEEFL & DKEFEEGRVL & QGGEEPEQAP & DEENMDWQDR & \\
\hline
\end{tabular}

\begin{tabular}{|c|c|c|c|c|}
\hline $\mathrm{r} \alpha 4$ & ALHRMREWDD & WKDTHPRGYG & NRQNMG & 34 \\
\hline $\mathrm{ma4}$ & ALHRMREWDD & WKDTHPRGYG & NRQNMG & . \\
\hline$m \alpha 4-b$ & ALERMQEWDD & WKDTHPRGYG & NRQNMG & 4 \\
\hline ha4 & TLHRAREWDD & WKDTHPRGYG & NRQNMG & \\
\hline уТар 42 & ETYKAREWDE & FKESHAKGSG & NTMNRG & \\
\hline
\end{tabular}

Figure 1 Alignment of deduced $\alpha 4$ and related molecules. Rat $\alpha 4$ (r $\alpha 4$; GenBank accession number AF000577), murine $\alpha 4$ (ma4; L31652), murine $\alpha 4-b$ (ma4-b; AJ010637), human $\alpha 4$ (ha4; Y08915) and yeast Tap42 (yTap42; U43890) were aligned by multiple sequence alignment. (Thin overline) PP2Ac-binding region; (broken overline) proline-rich SH3 binding-like motif; (bold overline) C-terminus conserved motif (anti- $\alpha 4$ antibodies were raised to this motif); (hatched underline) potential myristylation site. Amino acid numbers are denoted on the right.

Northern analysis showed ubiquitous expression of a single $\alpha 4$ transcript $(1.4 \mathrm{~kb})$ in the rat tissues examined, with the exception of the testes which did not express $\alpha 4$ (Fig. 3). An $\alpha 4-b$ isoform has been shown to be selectively expressed in murine testes and brain (Maeda et al. 1999); thus, the rat testes may express an $\alpha 4-b$ homologue. The $\mathrm{Nb} 2$ cells are lymphoid tumour cells and Northern analysis of commercial poly(A) ${ }^{+}$blots showed a $1.4 \mathrm{~kb} \alpha 4$ transcript in all the human immune tissues and cancer cell lines examined (Fig. 4).

a4 is glycosylated (45 kDa) and predominantly nuclear

Rat $\alpha 4$ has a predicted MW of $39 \cdot 1 \mathrm{kDa}$. When rat $\alpha 4$ was expressed in E. coli as a GST- $\alpha 4$ (V5-tagged) fusion protein, a protein band of about $65 \mathrm{kDa}$ was induced by
IPTG (Fig. 5A). Thrombin cleavage released $\alpha 4$ $(\sim 38 \mathrm{kDa})$ from the GST moiety $(27 \mathrm{kDa})$ (Fig. $5 \mathrm{~A})$. The rat V5-tagged $\alpha 4$ was expressed in COS-1 cells and Western analysis with anti-V5 antibodies detected a single immunoreactive band of $\sim 46 \mathrm{kDa}$ (Fig. 5B), indicating that the $\alpha 4$ protein $(45 \mathrm{kDa}$; the V5 epitope is $1.4 \mathrm{kDa}$ ) undergoes post-translational modification in eukaryotic cells.

Rat $\alpha 4$ is a component of the mTOR pathway and mTOR $(240 \mathrm{kDa})$ was detected in $\mathrm{Nb} 2$ and $\mathrm{Nb} 2-\mathrm{Sp}$ cells (Fig. 6A). Subcellular fractionation and Western analysis of quiescent $\mathrm{Nb} 2$ cell fractions with $\alpha 4$-specific antibodies showed a single immunoreactive band of $45 \mathrm{kDa}$ (Fig. 6B) which was not detected by preimmune serum (Fig. 6C). The $\mathrm{Nb} 2$ a4 localized predominantly in the nuclear fraction with trace amounts in the cytosol; the purity of the 
A.

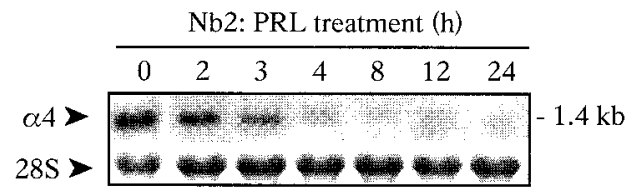

B.

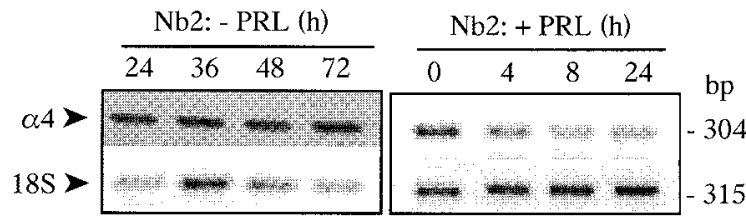

C.

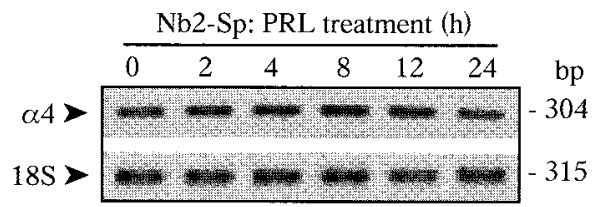

Figure 2 Prolactin (PRL) decreases $\alpha 4$ expression in $\mathrm{Nb} 2$, but not $\mathrm{Nb} 2-\mathrm{Sp}$ cells. $\mathrm{Nb} 2$ cells were growth-arrested for $20 \mathrm{~h}(-\mathrm{PRL}, 0 \mathrm{~h}$ controls) and then treated with PRL $(10 \mathrm{ng} / \mathrm{ml})$ for the indicated times. Total RNA was extracted for (A) Northern blotting $(1 \cdot 4 \mathrm{~kb}$ $\alpha 4$ mRNA) or (B, right-hand panel) RT-PCR (304 bp $\alpha 4$-specific product). (B, left-hand panel) RT-PCR analysis of Nb2 cells deprived of PRL for the indicated times. (C) RT-PCR analysis of $\mathrm{Nb} 2-\mathrm{Sp}$ cells treated with PRL $(10 \mathrm{ng} / \mathrm{ml})$. Ethidium bromidestained $28 \mathrm{~S}$ or the $18 \mathrm{~S}$ rRNA-specific PCR product $(315 \mathrm{bp})$ were used as internal standards. All PCR reactions were in the linear range of amplification. Each set of data is representative of two to three independent and reproducible experiments.

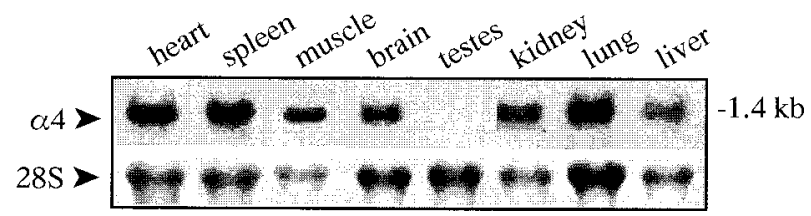

Figure 3 Tissue expression of $\alpha 4$. Northern analysis ( $25 \mu \mathrm{g}$ total $\mathrm{RNA} / \mathrm{ml}$ ) was performed with tissues from male rats. Ethidium bromide-stained $28 \mathrm{~S}$ rRNA was used as a loading control. Representative of tissue samples from two male rats.

fractions was confirmed by specific localization of the transcription factor TFIIB in the nucleus, glucokinase in the cytosol and PRLr in the membrane and cytosol (Fig. $6 \mathrm{~B})$. Human and murine $\alpha 4$ have been reported to associate with the catalytic subunit PP2A (see below) and PP2Ac was also found predominantly in the nuclear fraction with trace amounts in the microsomal and cytosolic fractions (Fig. 6B). Affinity-purified $\alpha 4$, after enzymatic deglycosylation, revealed the predicted $39 \mathrm{kDa}$ protein (Fig. 6D). Furthermore, PRL downregulation of the $\alpha 4$ mRNA in $\mathrm{Nb} 2$ cells was accompanied by a decrease of the $\alpha 4$ protein, of about twofold, which was detectable after 8-24 h of PRL treatment (Fig. 6E) but not earlier at $4 \mathrm{~h}$ (data not shown).
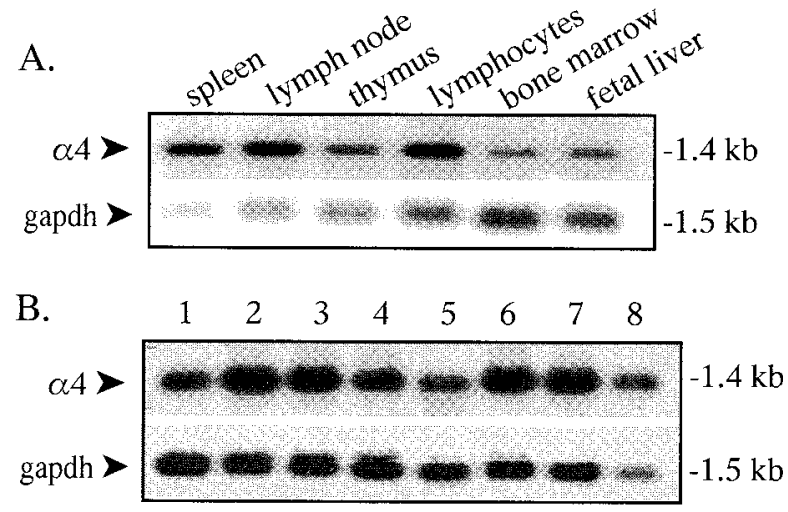

Figure 4 Human immune tissues and cancer cell lines express $\alpha 4$. Commercial poly $(A)^{+}$Northern blots of $(A)$ human immune tissues or (B) cancer cell lines. Glyceraldehyde-3-phosphate dehydrogenase (gapdh) (1.5 kb mRNA) was used as a loading control. In (B), lane 1, HL-60 promyelocytic leukaemia; lane 2, HeLa ovarian carcinoma; lane 3, K562 chronic myelogenous leukaemia; lane 4, MOLT-4 lymphoblastic leukaemia; lane 5, RAJI Burkitt's lymphoma; lane 6, SW480 colorectal adenocarcinoma; lane 7, A549 lung carcinoma; and lane 8, G361 melanoma.

\section{Rat a 4 interacts with $P P 2 A c$}

Human and murine $\alpha 4 / \alpha 4-\mathrm{b}$ bind specifically to PP2Ac (Murata et al. 1997, Chen et al. 1998, Inui et al. 1998, Maeda et al. 1999). Immunoprecipitation studies showed that Nb2 $\alpha 4$ interacted with PP2Ac (Fig. 7A). Pull-down assays of $\mathrm{Nb} 2$ cell lysates with immobilized GST- $\alpha 4$ fusion protein also revealed an interaction of the GST- $\alpha 4$ with PP2Ac (Fig. 7B). The $\alpha 4-P P 2 A c$ interaction was seen for as long as $8 \mathrm{~h}$ after PRL treatment (data not shown).

\section{TPA and PRL induce phosphorylation of a 4}

The $\alpha 4$ proteins have multiple potential phosphorylation sites for the serine/threonine kinase, PKC. Treatment with the tumour promoter TPA (activator of PKC) for 20 min has been shown to stimulate maximal phosphorylation of murine $\alpha 4$ and of several other proteins immunoprecipitated by anti- $\alpha 4$ antibodies (Kuwahara et al. 1994). In our study, $\mathrm{Nb} 2$ cells were radiolabelled with $\left[{ }^{32} \mathrm{P}\right]-$ orthophosphate ( \pm TPA or PRL) and $\alpha 4$ immunoprecipitates were analyzed for inducible phosphorylation of $\alpha 4$ and/or $\alpha 4$-associated proteins. PRL alone stimulated phosphorylation of at least three immunoprecipitated bands of $45 \mathrm{kDa}(\alpha 4), 50 \mathrm{kDa}$ and $120 \mathrm{kDa}$ as compared with controls (Fig. 8A). Samples treated with TPA alone also showed phosphorylation of these three bands and a $25 \mathrm{kDa}$ protein while the inactive phorbol $4 \alpha$-PHR alone had no effect (data not shown). PRL and TPA (20$40 \mathrm{nM})$ in combination enhanced inducible phosphorylation of 120, 50, 45 and $36 \mathrm{kDa}$ proteins (Fig. 8A and B). Thus, using both PRL and TPA (40 nM), these four $\left[{ }^{32} \mathrm{P}\right]$-immunoprecipitated bands from triplicate samples 
A.

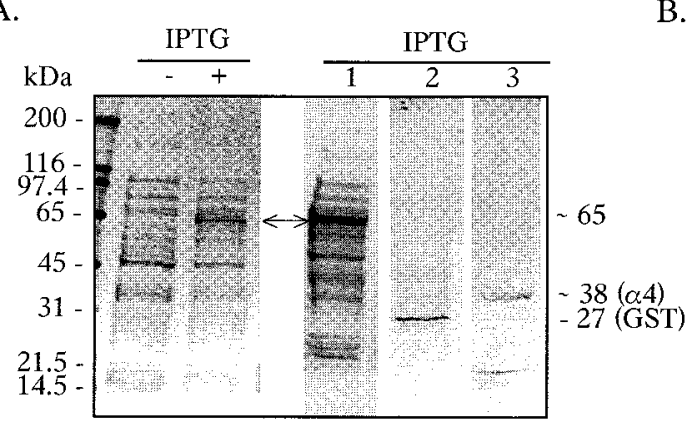

B.

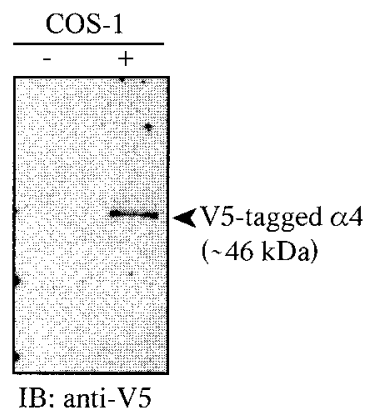

Figure 5 Eukaryotic $\alpha 4$ is $45 \mathrm{kDa}$. (A) The full length $\alpha 4-\mathrm{V} 5$-tagged cDNA was cloned into pGEX2T as described in Materials and Methods. GST- $\alpha 4-\mathrm{V} 5$ expression in E. coli was induced with $100 \mathrm{mM}$ IPTG $(+)$ while controls were untreated $(-)$. An IPTG-inducible band of $\sim 65 \mathrm{kDa}$ was obtained (arrows). Thrombin cleavage of the $65 \mathrm{kDa}$ protein (lane 1) released the $27 \mathrm{kDa}$ GST moiety (lane 2) and the $38 \mathrm{kDa}$ recombinant $\alpha 4$ (lane 3 ) as visualized with Coomassie Brilliant Blue R-250. (B) COS-1 cells were transfected with full-length $\alpha 4$ cDNA cloned into the pcDNA3·1-V5-tagged expression vector $(+)$ and compared with untransfected controls $(-)$. Cell lysates were used for Western blotting with anti-V5 antibody.

were excised from the gels and individually pooled. Phosphoamino acid analysis showed that the 120, 50, 45 and $36 \mathrm{kDa}$ bands were phosphorylated predominantly on serine/threonine residues (Fig. 8C, lanes 1-4). The $25 \mathrm{kDa}$ band that was phosphorylated by TPA alone (or TPA+PRL) was also analysed and was phosphorylated on serine, threonine and tyrosine residues (Fig. 8C, lane 5). The dark radioactive band in the solvent front of each sample was likely due to complete sample hydrolysis. Thus, PRL+TPA in combination stimulated serine/ threonine phosphorylation of $\alpha 4(45 \mathrm{kDa})$ and of at least three $\alpha 4$-associated proteins of 36,50 and $120 \mathrm{kDa}$. The $36 \mathrm{kDa}$ phosphoserine/threonine band may or may not be PP2Ac since PP2Ac was shown to be phosphorylated on tyrosine residues by serum stimulation (Chen et al. 1994). PRL-/TPA-induced serine phosphorylation of $\alpha 4$ was confirmed by immunoprecipitation with anti- $\alpha 4$ antibodies followed by immunoblotting with antiphosphoserine antibodies (Fig. 8D).

\section{Rapamycin inhibits $\mathrm{Nb} 2$ cell proliferation}

The $\alpha 4$ protein is a component of the rapamycin-sensitive mTOR pathway and the effects of rapamycin on $\mathrm{Nb} 2$ cell proliferation in response to PRL or IL-2, which also acts as a mitogen in these cells, was investigated. PRL- or IL-2-stimulated $\mathrm{Nb} 2$ cell proliferation was maximally inhibited by $100 \mathrm{nM}$ rapamycin (Fig. 9A). Rapamycin, at a concentration of $100 \mathrm{nM}$, inhibited $\mathrm{Nb} 2$ cell proliferation in response to increasing concentrations of PRL or IL-2 by about 50\% (Fig. 9B and C). Surprisingly, Nb2-Sp cell proliferation was not affected by rapamycin at concentrations as high as $10 \mu \mathrm{M}$ (Fig. 9D). a 4 overexpression inhibits PRL signalling to the IRF-1 gene

$\mathrm{Nb} 2$ sensitivity to rapamycin indicates a functional mTOR signalling pathway. The possibility of an effect of the mTOR pathway on PRLr action was examined by ectopic overexpression of $\alpha 4$ in COS-1 cells. Control COS-1 cells expressed $\alpha 4$ and Stat $1 \alpha$ proteins (Fig. 10A, lane 1). Endogenous levels of Stat $1 \alpha$ were increased about threefold by transient transfection of the Stat $1 \alpha$ construct (Fig. 10A, lanes 2 and 3). When co-transfected with the a 4 construct, COS-1 cells showed a fivefold increase of endogenous $\alpha 4$ without any adverse effect on Stat $1 \alpha$ protein synthesis (Fig. 10A, lane 4). The antisense- $\alpha 4$ construct used did not obliterate endogenous levels of $\alpha 4$ but was used as an additional control. CAT assays indicated that overexpression of $\alpha 4$ consistently decreased basal IRF-1 promoter activity by $30-40 \%$ and PRL-stimulated IRF-1 promoter activity by $40-50 \%$ (Fig. 10B). Studies reporting OAS inhibition of IRF-1 promoter activity also showed inhibition of both basal and PRL-inducible IRF-1 promoter activities (McAveney et al. 2000). Taken together, the present data suggest that ectopic overexpression of $\alpha 4$ inhibits PRLr signalling to the IRF-1 promoter.

\section{Discussion}

The present study showed that PRL downregulated $\mathrm{Nb} 2$ a 4 mRNA expression which was accompanied by a modest decrease in $\alpha 4$ protein levels. PRL also induced phosphorylation of the $\mathrm{Nb} 2 \alpha 4$ protein, an effect that was enhanced by a combination of PRL and TPA. The $\alpha 4$ is a glycoprotein and was predominantly nuclear. Similar to 
A.

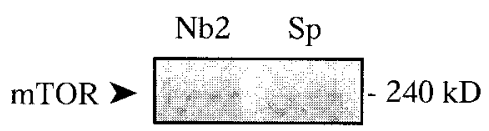

B.

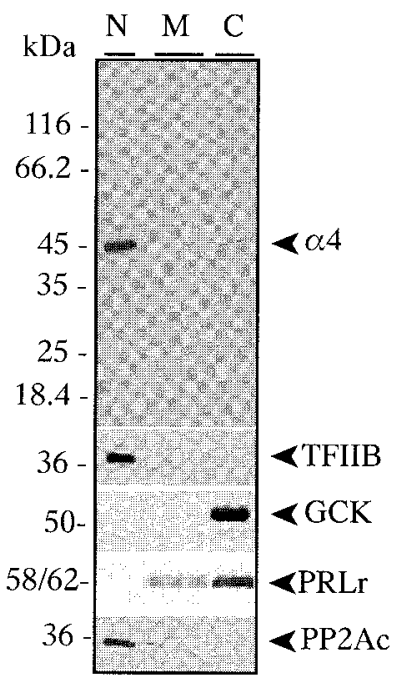

C.

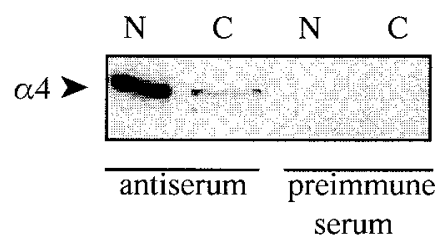

D.

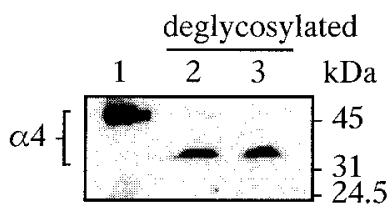

E.
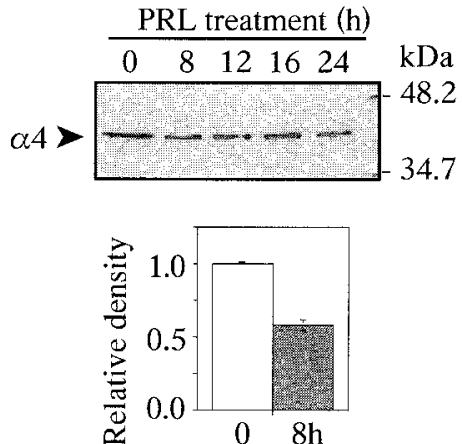

Figure $6 \mathrm{Nb} 2 \alpha 4$ is glycosylated and predominantly nuclear. (A) Western analysis of immunoprecipitated mTOR in Nb2 and Nb2-Sp cell lysates. (B) Nuclear ( $;$; $800 \boldsymbol{g}$ pellet), microsomal (M; $100000 \boldsymbol{g}$ pellet) or cytosolic (C; $100000 \mathrm{~g}$ supernatant) fractions from quiescent $\mathrm{Nb} 2$ cells were used for Western analysis of $\alpha 4$ (8-20 $\mu$ g protein/lane; representing $4 \%$ of total protein in each fraction). Protein markers used were: TFIIB, glucokinase (GCK) and PRLr. (C) Nuclear (N; $800 \mathrm{~g}$ pellet) and cytosolic (C; $800 \mathrm{~g}$ supernatant) fractions from $\mathrm{Nb} 2$ cell lysates were Western blotted (20 $\mu \mathrm{g}$ protein/lane) with $\alpha 4$ antiserum or preimmune serum. (D) Affinity-purified Nb2 $\alpha 4$ (lane 1) was deglycosylated under denaturing (lane 2) or non-denaturing (lane 3 ) conditions and Western blotted with anti- $\alpha 4$ antibodies. In (A-D), each set of data is representative of two to three independent experiments. (E) Upper: Western analysis of $\alpha 4$ in arrested ( $0 \mathrm{~h}$ ) or PRL-treated Nb2 cell lysates (40 $\mu \mathrm{g}$ protein/lane); lower: densitometric analysis of the 0 and $8 \mathrm{~h}$ time-points $(n=6)$.

human and murine $\alpha 4 / \alpha 4-\mathrm{b}$ proteins, the rat $(\mathrm{Nb} 2) \alpha 4$ bound specifically to PP2Ac and to other proteins which are as yet unidentified.

Murine $\alpha 4$ was initially found as a surface protein by external biotinylation (Kuwahara et al. 1994). However, murine $\alpha 4$ (Inui et al. 1995) and rat $\alpha 4$ (present study) have no apparent transmembrane domain or a leader sequence. The mammalian $\alpha 4$ proteins have a C-terminus myristylation-like site (GNRQNMG) (see Fig. 1). This motif, when located at the $\mathrm{N}$-terminus, was reported to be commonly used by membrane-attached molecules involved in signal transduction (Resh 1994). Thus, it has been suggested that this C-terminus motif of $\alpha 4$ may be used for dynamic movement in signal transduction and not for direct membrane attachment (Inui et al. 1995). Our study showed cytosolic $\alpha 4$ in $\mathrm{Nb} 2$ cells as anticipated but, surprisingly, the $\alpha 4$ protein was predominantly in the cell nuclei. We also showed that the $\mathrm{Nb} 2 \alpha 4$ was an $\mathrm{O}-/ \mathrm{N}-$ linked glycoprotein, without an apparent leader sequence. Protein glycosylation is classically viewed to occur exclusively on extracellular and luminal polypeptides. However, O-glycosylation at specific serine or threonine residues by single $\beta-N$-acetylglucosamine moieties (O-GlcNAc) has been reported in many eukaryotic nuclear and cytoplasmic proteins (Hart 1997, Comer \& Hart 1999). The enzymes for the attachment or removal of the O-GlcNAc moieties are cytosolic and/or nuclear (Comer \& Hart 2000). O-GlcNAc modification of proteins has been implicated in nuclear transport (Miller \& Hanover 1994) and has been suggested to act as an alternative nuclear transport signal on some proteins (Hubert et al. 1989, Duverger et al. 1996). Thus, it is possible that cytosolic O-GlcNAc 
A.

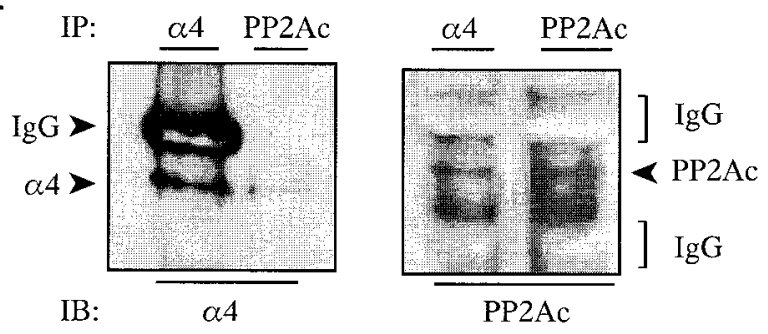

B.

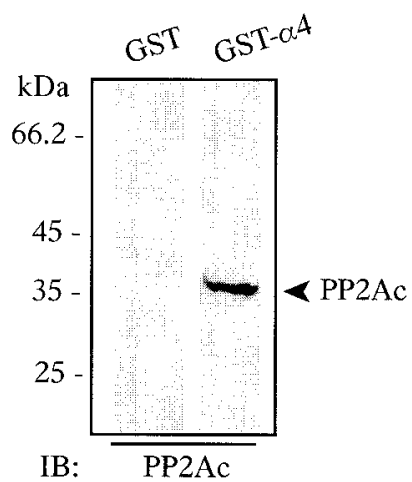

Figure $7 \alpha 4$ interacts with PP2Ac. (A) Nb2 cell lysates were immunoprecipitated (IP) with anti- $\alpha 4$ or anti-PP2Ac and immunocomplexes were resolved by SDS-PAGE. Immunoblotting (IB) with anti- $\alpha 4$ or PP2Ac was performed. (B) Nb2 cell lysates were incubated with GST or GST- $\alpha 4$ fusion proteins conjugated to glutathione-Sepharose beads, precipitates were separated by SDS-PAGE and immunoblotted with anti-PP2Ac antibody.

modification of the $\mathrm{Nb} 2 \alpha 4$ phosphoprotein contributed to its nuclear localization. Interestingly, O-GlcNAc modification has also been implicated in signal transduction cascades (Wells et al. 2001) and to have functional roles in gene expression at the level of transcription and translation (Comer \& Hart 1999). All known O-GlcNAc proteins identified to date occur as phosphorylated proteins and, in several cases, phosphorylation and O-GlcNAc modification are reciprocal, occurring at the same or adjacent hydroxyl moieties (Comer \& Hart 2000).

It is also possible that PP2Ac (and other $\alpha 4$-associated molecules) act as chaperone(s) to target $\alpha 4$ into the nucleus. PP2Ac has been shown to undergo differential methylation, conformational changes and redistribution in the nucleus versus cytoplasm during progression into the cell cycle (Turowski et al. 1995). Particulate distribution of PP2A has also been reported (Sim et al. 1994, 1998). Nuclear PP2A has been shown to dephosphorylate the protein kinase A-phosphorylated cAMP-regulatory element binding protein (CREB) to regulate CREB transcriptional stimulation (Wadzinski et al. 1993), to inhibit telomerase activity in human breast cancer cells (Li et al. 1997) and to inhibit transcriptional activation of c-Jun and AP-1 (Al-Murrani et al. 1999). Conversely, it is conceiv- able that $\alpha 4$ itself (with $O$-glycosylation) may act as a chaperone targeting the phosphatase activity of PP2Ac into the cell nucleus. This is analogous to the nuclear translocation of PRL through its interaction with cyclophilin B and where PRL was viewed as a scaffold protein targeting the peptidylprolyl isomerase activity of cyclophilin B to transcription factors (Rycyzyn et al. 2000).

Murine $\alpha 4$ was initially detected as a protein that was inducibly phosphorylated by TPA (Kuwahara et al. 1994) and phosphorylation was exclusively on serine residues (Murata et al. 1997). In our study, phosphorylation of the rat $(\mathrm{Nb} 2) \alpha 4$ on serine/threonine residues was induced by PRL or TPA and further enhanced by PRL+TPA. The phosphorylated proteins of 36,50 and $120 \mathrm{kDa}$ may be associated with $\alpha 4$ or its protein partner PP2Ac. Increased phosphorylation of $\alpha 4$ by PRL and TPA has additional significance in $\mathrm{Nb} 2$ cells. TPA is known to enhance PRL-stimulated $\mathrm{Nb} 2$ c-myc expression, DNA synthesis and cell proliferation but TPA alone has no effect (Gertler et al. 1985, Murphy et al. 1988). The effector of this TPA (and PRL) action is not known but the present data suggest that it may be $\alpha 4$. Thus, PRL downregulation of the $\alpha 4$ mRNA and protein, albeit not more than twofold, was accompanied by PRL-inducible phosphorylation of $\alpha 4$. These events, in combination, may act to regulate efficiently the action of $\alpha 4$ in the proliferation of the $\mathrm{Nb} 2$ cells.

The immunosuppressant rapamycin is a potent inhibitor of IL-2-induced T-cell proliferation and it also inhibited growth of IL-2-dependent murine cytotoxic T-cell line, CTLL-2, by $50-70 \%$ via inhibition of G- to S-phase progression (Morice et al. 1993a,b). Our study showed that rapamycin partially inhibited $(\sim 50 \%) \mathrm{Nb} 2$ cell proliferation in response to optimal doses of PRL or IL-2, but the drug had no effect on the proliferation of the PRLindependent $\mathrm{Nb} 2-\mathrm{Sp}$ cell line. The molecular basis of rapamycin resistance in $\mathrm{Nb} 2-\mathrm{Sp}$ cells is not known. However, resistance to growth inhibition by rapamycin may arise from mutations in TOR/mTOR (Luo et al. 1996) or any of its downstream components including Tap42, FKBP and p70S6K (Heitman et al. 1991, Dumont et al. 1995, Fruman et al. 1995, Di Como \& Arndt 1996, Brennan et al. 1999). Introduction of the murine a cDNA into Jurkat cells or the increased association of $\mathrm{PP} 2 \mathrm{Ac} / \alpha 4$ in culture with low serum concentration have also been reported to confer rapamycin resistance to cells (Inui et al. 1998). The rapamycin sensitivity of the $\alpha 4-\mathrm{PP} 2 \mathrm{~A}$ interaction is controversial. While formation of a GST- $\alpha 4$ fusion protein with PP2A in COS-7 or Jurkat cell lines was shown to be rapamycin sensitive (Murata et al. 1997, Inui et al. 1998), a4-PP2A interaction in human embryonic kidney 293 cells was shown to be constitutive and rapamycin insensitive (Nanahoshi et al. 1998). Recently, mTOR was shown to be a direct target of the phosphoinositide 3'-kinase 
A.

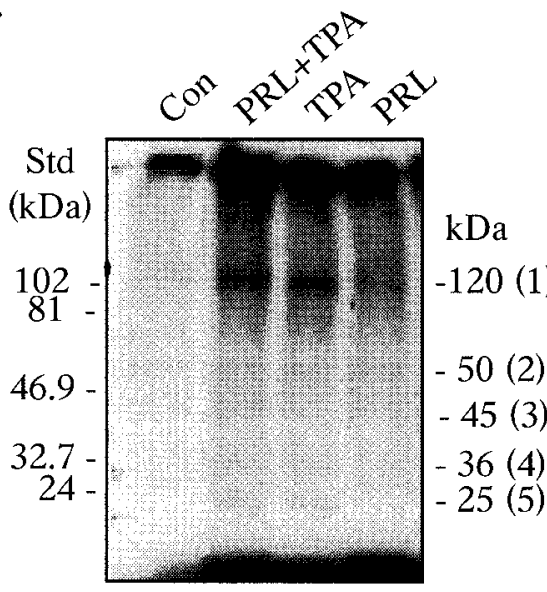

B.

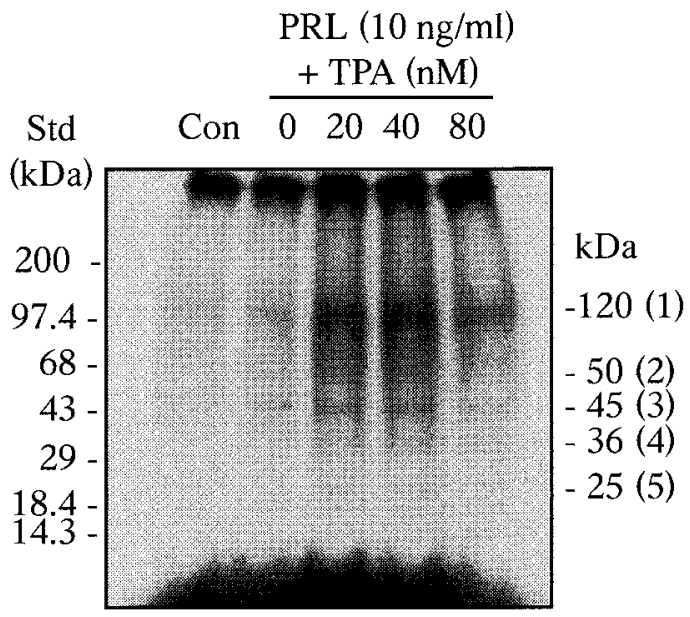

C.

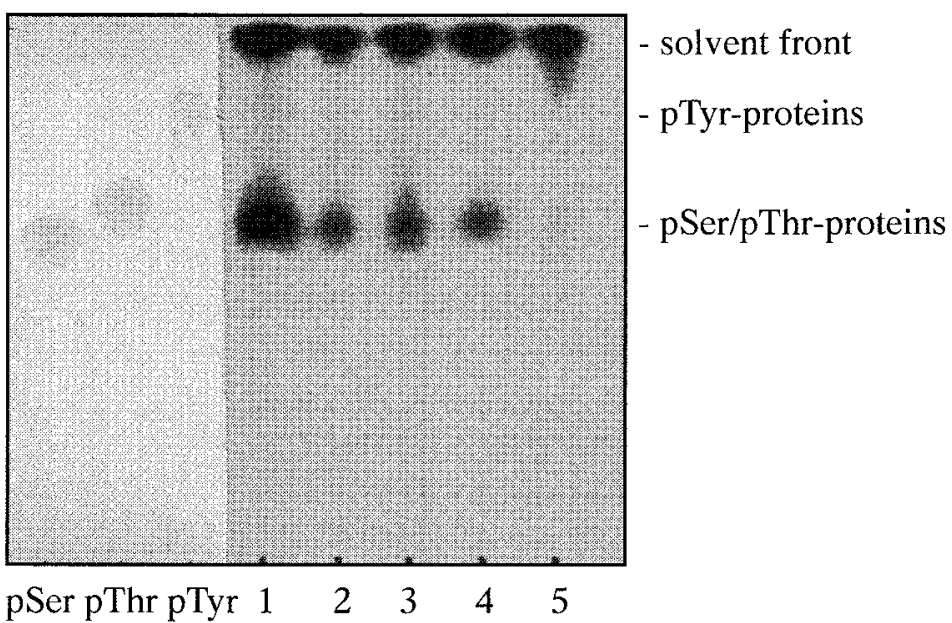

D.

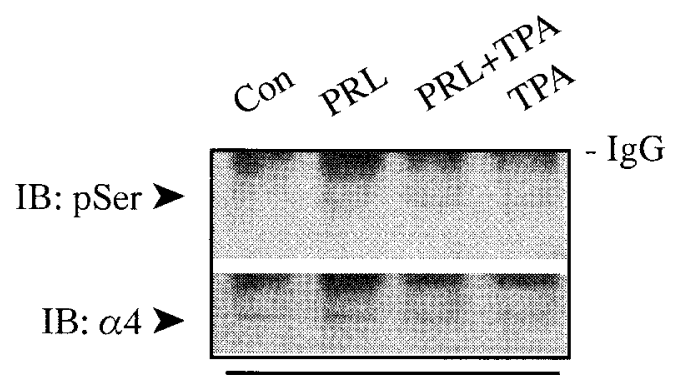

IP: $\alpha 4$

Figure 8 PRL-/TPA-inducible phosphorylation of $\alpha 4$. (A, B) Nb2 cells were radiolabelled with

$\left[{ }^{32} \mathrm{P}\right]$-orthophosphate in the presence of PRL $(10 \mathrm{ng} / \mathrm{ml})$ and/or TPA $(\mathrm{A}, 20 \mathrm{nM}$; B, as indicated) for $20 \mathrm{~min}$. Controls (Con) were untreated. Total cell lysates were immunoprecipitated with anti- $\alpha 4$ antibodies.

Immuno-complexes were analyzed by SDS-PAGE and autoradiography. The MWs of the radiolabelled bands $(1-5)$ are indicated on the right. (C) Cells were radiolabelled in the presence of PRL+TPA (40 nM).

Anti- $\alpha$-immunoprecipitated bands $1-5$ from triplicate samples were excised from the gel for phosphoamino acid analysis. Thin layer chromatography and autoradiography of acid-hydrolyzed samples and standards (pSer, pThr and pTyr) were performed. (D) Immunopreciptation (IP) and blotting (IB) of Nb2 cell lysates after PRL \pm TPA $(20 \mathrm{nM})$ treatment. Each set of data is representative of two to three independent experiments. 
A. $\quad \mathrm{Nb} 2$

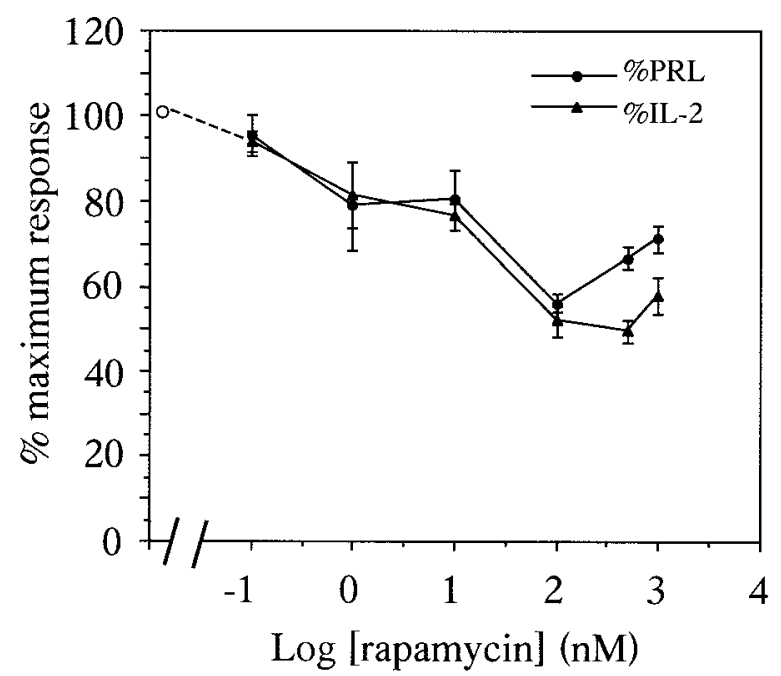

C. $\mathrm{Nb} 2$

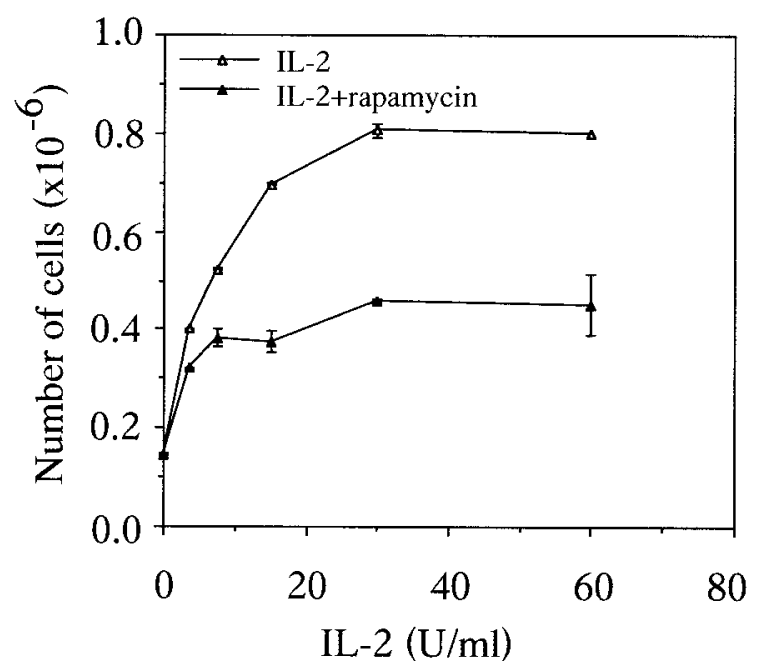

B. $\quad \mathrm{Nb} 2$

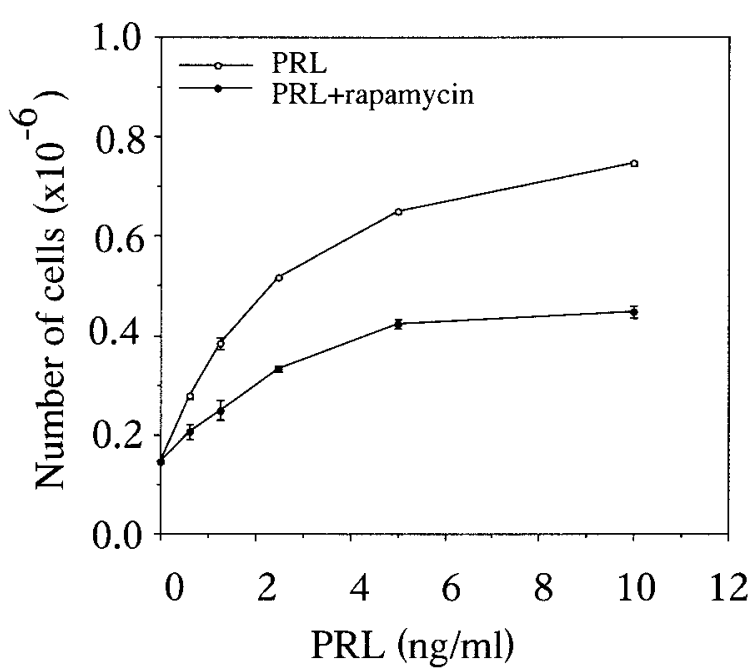

D. $\quad \mathrm{Nb} 2-\mathrm{Sp}$

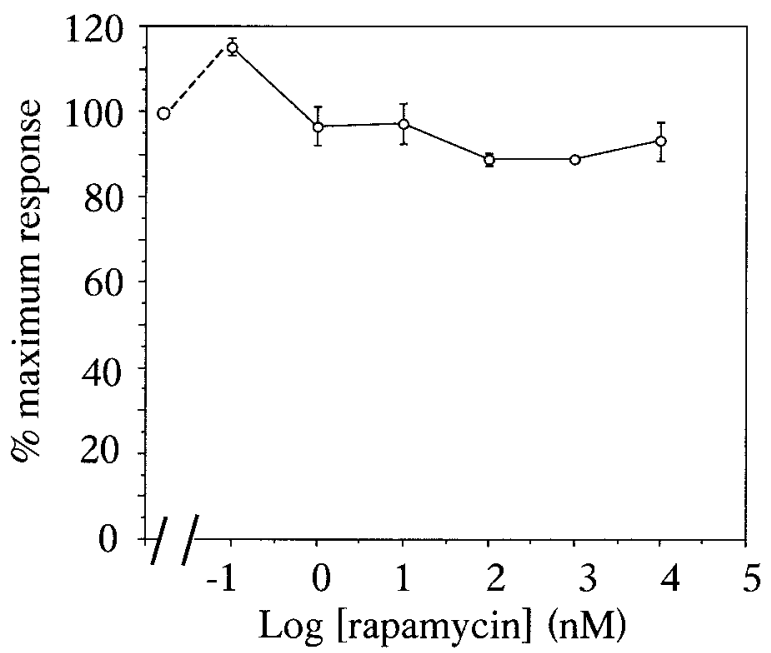

Figure 9 Rapamycin inhibits proliferation of Nb2 but not Nb2-Sp cells. (A) Quiescent Nb2 cells were treated with PRL (10 ng/ml) or IL-2 $(30 \mathrm{U} / \mathrm{ml})$ and increasing concentrations of rapamycin. Controls received mitogen alone. Cell count was determined in a 3-day bioassay and data plotted as a \% of the maximum response seen in controls. (B and C) Quiescent Nb cells were treated with $100 \mathrm{nM}$ rapamycin with increasing doses of (B) PRL or (C) IL-2 for a 3-day bioassay. Controls received no rapamycin. (D) Nb2-Sp cells were treated with rapamycin while controls were untreated. Data are plotted as in (A). Each graph is representative of two to three independent experiments, each treatment done in triplicate. Values are means \pm S.D.

(PI3K)-AKT/protein kinase B signalling pathway in mitogen-stimulated cells and the activation status of the PI3K-AKT pathway in cancer cells was suggested as an important determinant of cellular sensitivity to rapamycin (Sekulic et al. 2000).

Our study also demonstrated that overexpression of the $\alpha 4$ protein in COS-1 cells inhibited PRLr signalling to the IRF-1 promoter, an effect that was not due to global protein shutdown since the transfected Stat $1 \alpha$ protein remained elevated. Transient overexpression of $\alpha 4$ in COS-7 cells has also been reported to have no effect on protein synthesis (Chung et al. 1999). Taken together, PRL downregulation of $\alpha 4 \mathrm{mRNA}$ and protein and/or the modulation of $\alpha 4$ protein action through PRLinducible phosphorylation may facilitate activation of PRL-responsive genes (e.g. IRF-1) culminating in $\mathrm{Nb} 2$ cell proliferation. The constitutive expression of $\alpha 4$ in $\mathrm{Nb} 2-\mathrm{Sp}$ cells may not be inconsistent with this model, for 
A.

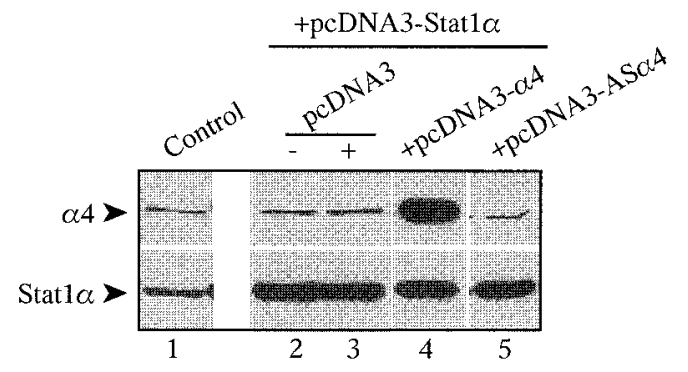

B.

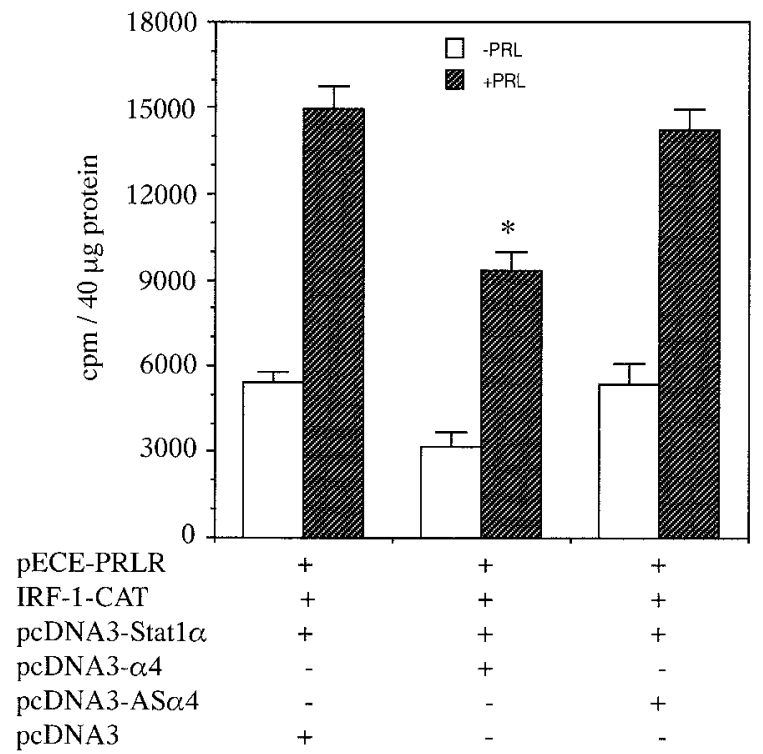

Figure 10 Overexpression of $\alpha 4$ inhibits IRF-1 promoter activity. COS-1 cells were transiently transfected with expression contructs of the Nb2 form of the PRLr, $1.7 \mathrm{~kb}$ IRF-1-CAT reporter, Stat $1 \alpha$ and either $\alpha 4$ or antisense $\alpha 4$ or the pcDNA3 vector.

Untransfected COS-1 cells served as controls. Cells were made quiescent overnight in medium containing $1 \%$ horse serum prior to treatment with or without PRL $(100 \mathrm{ng} / \mathrm{ml})$ for $24 \mathrm{~h}$. Cell lysates were prepared for (A) Western analysis or (B) CAT enzyme activity. In (A), the immunoblot (20 $\mu$ g protein/sample; - PRL) was probed sequentially with anti- $\alpha 4$ or anti-Stat $1 \alpha$ antibodies. Lane 1, untransfected COS-1 cells; lanes 2-5, COS-1 cells transfected with pcDNA3-Stat $1 \alpha$ and with (+) or without $(-)$ additional pcDNA3 vector (lanes 2 and 3 ) or with pcDNA3- $\alpha 4$ (lane 4 ) or antisense pcDNA3-AS $\alpha 4$ (lane 5). In (B), CAT assay was performed with equal amounts of protein for each sample. Representative of four independent experiments, with each treatment assayed in triplicate. Values are means \pm S.D. ${ }^{*} P<0 \cdot 05$.

these cells are insensitive to rapamycin, indicating that mTOR signalling may be defective or sub-optimal in $\mathrm{Nb} 2-\mathrm{Sp}$ cells. Inhibition of PP2A, the $\alpha 4$ partner, has been shown to induce serine/threonine phosphorylation, subcellular redistribution and functional inhibition of Stat3 (Woetmann et al. 1999). The role of the mTOR components $(\alpha 4 / \mathrm{PP} 2 \mathrm{~A})$ in modulating PRLr action through Stat activity is under further investigation.

\section{Acknowledgements}

We would like to thank Dr Li-yuan Yu-Lee (Baylor College of Medicine) for excellent advice and for kindly providing the constructs and COS-1 cells used for the CAT assays. R T M B was supported in part by a Cancer Research and Education (CaRE)-Nova Scotia trainee award, with funding from the Faculty of Medicine, Dalhousie University. L M J was supported by a CaRENova Scotia Summer Studentship. C K L T was a Scholar of the Canadian Institutes of Health Research (CIHR). This study was supported by CIHR grant MOP12895 (CKLT).

\section{References}

Ali S, Chen Z, Lebrun JJ, Vogel W, Kharitonenkov A, Kelly PA \& Ullrich A 1996 PTP1D is a positive regulator of the prolactin signal leading to beta-casein promoter activation. EMBO Journal 15 135-142.

Al-Murrani SW, Woodgett JR \& Damuni Z 1999 Expression of I2PP2A, an inhibitor of protein phosphatase $2 \mathrm{~A}$, induces c-Jun and AP-1 activity. Biochemical Journal 341 293-298.

Ausubel FM, Brent R, Kingston RE, Moore DD, Seidman JG, Smith JA \& Struhl K 1994 Unit 16: Expression and purification of glutathione s-transferase fusion proteins. In Current Protocols in Molecular Biology. New York: Greene Publishing Associates and Wiley-Interscience. John Wiley \& Sons.

Brennan P, Babbage JW, Thomas G \& Cantrell D 1999 p70(s6k) integrates phosphatidylinositol 3-kinase and rapamycin-regulated signals for E2F regulation in T lymphocytes. Molecular and Cellular Biology 19 4729-4738.

Campbell GS, Argetsinger LS, Ihle JN, Kelly PA, Rillema JA \& Carter-Su C 1994 Activation of JAK2 tyrosine kinase by prolactin receptors in $\mathrm{Nb} 2$ cells and mouse mammary gland explants. PNAS 91 5232-5236.

Chen J, Parsons S \& Brautigan DL 1994 Tyrosine phosphorylation of protein phosphatase $2 \mathrm{~A}$ in response to growth stimulation and $\mathrm{v}$-src transformation of fibroblasts. Journal of Biological Chemistry 269 7957-7962.

Chen J, Peterson RT \& Schreiber SL 1998 Alpha 4 associates with protein phosphatases 2A, 4, and 6. Biochemical and Biophysical Research Commununications 247 827-832.

Chung H, Nairn AC, Murata K \& Brautigan DL 1999 Mutation of Tyr307 and Leu309 in the protein phosphatase 2A catalytic subunit favors association with the alpha 4 subunit which promotes dephosphorylation of elongation factor-2. Biochemistry 38 10371-10376.

Clevenger CV \& Medaglia MV 1994 The protein tyrosine kinase $\mathrm{p} 59^{\mathrm{fyn}}$ is associated with prolactin (PRL) receptor and is activated by PRL stimulation of T-lymphocytes. Molecular Endocrinology $\mathbf{8}$ 674-681.

Clevenger CV, Sillman AL \& Prystowsky MB 1990 Interleukin-2 driven nuclear translocation of prolactin in cloned T-lymphocytes. Endocrinology 127 3151-3159.

Clevenger CV, Torigoe T \& Reed JC 1994 Prolactin induces rapid phosphorylation and activation of prolactin receptor associated Raf-1 kinase in a T-cell line. Journal of Biological Chemistry 269 5559-5565.

Clevenger CV, Freier DO \& Kline JB 1998 Prolactin receptor signal transduction in cells of the immune system. Journal of Endocrinology 157 187-197.

Comer FI \& Hart GW 1999 O-GlcNAc and the control of gene expression. Biochimica et Biophysica Acta 1473 161-171. 
Comer FI \& Hart GW 2000 O-Glycosylation of nuclear and cytosolic proteins. Dynamic interplay between O-GlcNAc and O-phosphate. Journal of Biological Chemistry 275 29179-29182.

Cutler NS, Heitman J \& Cardenas ME 1999 TOR kinase homologs function in a signal transduction pathway that is conserved from yeast to mammals. Molecular and Cellular Endocrinology 155 135-142.

Di Como CJ \& Arndt KT 1996 Nutrients, via the Tor proteins, stimulate the association of Tap 42 with type $2 \mathrm{~A}$ phosphatases. Genes and Development 10 1904-1916.

Dodd F, Limoges M, Boudreau RTM, Rowden G, Murphy PR \& Too CKL 2000 L-arginine inhibits apoptosis via an NO-dependent mechanism in $\mathrm{Nb} 2$ lymphoma cells. Journal of Cellular Biochemistry 77 624-634.

Dumont FJ, Staruch MJ, Grammer T, Blenis J, Kastner CA \& Rupprecht KM 1995 Dominant mutations confer resistance to the immunosuppressant, rapamycin, in variants of a $\mathrm{T}$ cell lymphoma. Cellular Immunology 163 70-79.

Duverger E, Roche AC \& Monsigny M 1996 N-acetylglucosaminedependent nuclear import of neoglycoproteins. Glycobiology 6 381-386.

Fruman DA, Wood MA, Gjertson CK, Katz HR, Burakoff SJ \& Bierer BE 1995 FK506 binding protein 12 mediates sensitivity to both FK506 and rapamycin in murine mast cells. European Journal of Immunology 25 563-571.

Fulton D, Gratton JP, McCabe TJ, Fontana J, Fujio Y, Walsh K, Franke TF, Papapetropoulos A \& Sessa WC 1999 Regulation of endothelium-derived nitric oxide production by the protein kinase Akt. Nature 399 597-601.

Gertler A, Walker A \& Friesen HG 1985 Enhancement of human growth hormone-stimulated mitogenesis of $\mathrm{Nb} 2$ node lymphoma cells by 12-O-tetradecanoyl-phorbol-13-acetate. Endocrinology 116 $1636-1644$.

Hart GW 1997 Dynamic O-linked glycosylation of nuclear and cytoskeletal proteins. Annual Review of Biochemistry 66 315-335.

Heitman J, Movva NR \& Hall MN 1991 Targets for cell cycle arrest by the immunosuppressant rapamycin in yeast. Science $\mathbf{2 5 3}$ 905-909.

Hubert J, Seve AP, Facy P \& Monsigny M 1989 Are nuclear lectins and nuclear glycoproteins involved in the modulation of nuclear functions? Cell Differentiation and Developmen 27 69-81.

Inui S, Kuwahara K, Mizutani J, Maeda K, Kawai T, Nakayasu H \& Sakaguchi N 1995 Molecular cloning of a cDNA clone encoding a phosphoprotein component related to the Ig receptor-mediated signal transduction. Journal of Immunology 154 2714-2723.

Inui S, Sanjo H, Maeda K, Yamamoto H, Miyamoto E \& Sakaguchi N 1998 Ig receptor binding protein 1 (alpha4) is associated with a rapamycin-sensitive signal transduction in lymphocytes through direct binding to the catalytic subunit of protein phosphatase $2 \mathrm{~A}$. Blood 92 539-546.

Jiang Y \& Broach JR 1999 Tor proteins and protein phosphatase 2A reciprocally regulate Tap42 in controlling cell growth in yeast. EMBO Journal 18 2782-2792.

Johnson LM \& Too CKL 2001 Prolactin, interleukin-2 and FGF-2 stimulate expression, nuclear distribution and DNA-binding of rat homolog of pombe $\mathrm{Cdc} 5$ in $\mathrm{Nb} 2 \mathrm{~T}$ lymphoma cells. Molecular and Cellular Endocrinology 184 151-161.

Kuwahara K, Matsuo T, Nomura J, Igarashi H, Kimoto M, Inui S \& Sakaguchi N 1994 Identification of a 52-kDa molecule (p52) coprecipitated with the Ig receptor-related MB-1 protein that is inducibly phosphorylated by the stimulation with phorbol myristate acetate. Journal of Immunology 152 2742-2752.

Li H, Zhao LL, Funder JW \& Liu JP 1997 Protein phosphatase 2A inhibits nuclear telomerase activity in human breast cancer cells. Journal of Biological Chemistry 272 16729-16732.

Luo Y, Marx SO, Kiyokawa H, Koff A, Massague J \& Marks AR 1996 Rapamycin resistance tied to defective regulation of $\mathrm{p} 27$ Kip1. Molecular and Cellular Biology 16 6744-6751.
McAveney KM, Book ML, Ling P, Chebath J \& Yu-Lee L 2000 Association of $2^{\prime}, 5^{\prime}$-oligoadenylate synthetase with the prolactin (PRL) receptor: alteration in PRL-inducible Stat1 (signal transducer and activator of transcription 1) signaling to the IRF-1 (interferonregulatory factor 1) promoter. Molecular Endocrinology 14 295-306.

Maeda K, Inui S, Tanaka H \& Sakaguchi N 1999 A new member of the alpha4-related molecule (alpha4-b) that binds to the protein phosphatase $2 \mathrm{~A}$ is expressed selectively in the brain and testis. European Journal of Biochemistry 264 702-706.

Miller MW \& Hanover JA 1994 Functional nuclear pores reconstituted with beta 1-4 galactose-modified O-linked $\mathrm{N}$-acetylglucosamine glycoproteins. Journal of Biological Chemistry 269 9289-9297.

Morice WG, Brunn GJ, Wiederrecht G, Siekierka JJ \& Abraham RT 1993a Rapamycin-induced inhibition of p34 cdc2 kinase activation is associated with G1/S-phase growth arrest in T lymphocytes. Journal of Biological Chemistry 268 3734-3738.

Morice WG, Wiederrecht G, Brunn GJ, Siekierka JJ \& Abraham RT $1993 b$ Rapamycin inhibition of interleukin-2-dependent p33 cdk2 and p34 cdc2 kinase activation in T lymphocytes. Journal of Biological Chemistry 268 22737-22745.

Murata K, Wu J \& Brautigan DL 1997 B cell receptor-associated protein alpha4 displays rapamycin-sensitive binding directly to the catalytic subunit of protein phosphatase 2A. PNAS $\mathbf{9 4}$ 10624-10629.

Murphy PR, DiMattia GE \& Friesen HG 1988 Role of calcium in prolactin-stimulated c-myc gene expression in $\mathrm{Nb} 2$ lymphoma cells. Endocrinology 122 2476-2485.

Nanahoshi M, Nishiuma T, Tsujishita Y, Hara K, Inui S, Sakaguchi N \& Yonezawa K 1998 Regulation of protein phosphatase 2A catalytic activity by alpha4 protein and its yeast homolog Tap42. Biochemical and Biophysical Research Communications 251 520-526.

Neumann JR, Morency CA \& Russian KO 1987 A novel rapid assay for chloramphenicol acetyltransferase gene expression. BioTechniques 5 444-447.

Onda M, Inui S, Maeda K, Suzuki M, Takahashi E \& Sakaguchi N 1997 Expression and chromosomal localization of the human alpha 4/IGBP1 gene, the structure of which is closely related to the yeast TAP42 protein of the rapamycin-sensitive signal transduction pathway. Genomics 46 373-378.

Rao Y-P, Buckley DJ, Olson MD \& Buckley AR 1995 Nuclear translocation of prolactin: collaboration of tyrosine kinase and protein kinase $\mathrm{C}$ activation in rat $\mathrm{Nb} 2$ node lymphoma cells. Journal of Cellular Physiology 163 266-267.

Rayhel EJ, Fields TJ, Albright JW, Diamantstein T \& Hughes JP 1988 Interleukin 2 and a lactogen regulate proliferation and protein phosphorylation in Nb2 cells. Biochemical Journal 249 333-338.

Resh MD 1994 Myristylation and palmitylation of src family members: the fats of the matter. Cell 76 411-413.

Rui H, Kirken RA \& Farrar WL 1994 Activation of receptorassociated tyrosine kinase JAK2 by prolactin. Journal of Biological Chemistry 269 5364-5368.

Rycyzyn MA, Reilly SC, O'Malley K \& Clevenger CV 2000 Role of cyclophilin $\mathrm{B}$ in prolactin signal transduction and nuclear retrotranslocation. Molecular Endocrinology 14 1175-1186.

Sehgal SN 1998 Rapamune (RAPA, rapamycin, sirolimus): mechanism of action immunosuppressive effect results from blockade of signal transduction and inhibition of cell cycle progression. Clinical Biochemistry 31 335-340.

Sekulic A, Hudson CC, Homme JL, Yin P, Otterness DM, Karnitz LM \& Abraham RT 2000 A direct linkage between the phosphoinositide 3-kinase-AKT signaling pathway and the mammalian target of rapamycin in mitogen-stimulated and transformed cells. Cancer Research 60 3504-3513.

Sim AT, Ratcliffe E, Mumby MC, Villa-Moruzzi E \& Rostas JA 1994 Differential activities of protein phosphatase types 1 and 2A in cytosolic and particulate fractions from rat forebrain. Journal of Neurochemistry 62 1552-1559. 
Sim AT, Collins E, Mudge LM \& Rostas JA 1998 Developmental regulation of protein phosphatase types 1 and $2 \mathrm{~A}$ in post-hatch chicken brain. Neurochemical Research 23 487-491.

Stevens AM, Wang Y-F, Sieger KA, Lu H-F \& Yu-Lee L 1995 Biphasic transcriptional regulation of the interferon regulatory factor-1 gene by prolactin: involvement of $\gamma$-interferon-activated sequence and Stat-related proteins. Molecular Endocrinology 9 513-525.

Thomas G \& Hall MN 1997 TOR signalling and control of cell growth. Current Opinions in Cell Biology 9 782-787.

Too CKL 1997 Differential expression of elongation factor-2, alpha4 phosphoprotein and Cdc5-like protein in prolactin-dependent/ independent rat lymphoid cells. Molecular and Cellular Endocrinology 131 221-232.

Too CKL, Walker A, Murphy PR, Cragoe EJ Jr, Jacobs HK \& Friesen HG 1987 Identification of amiloride-sensitive $\mathrm{Na}^{+} / \mathrm{H}^{+}$ exchange in rat $\mathrm{Nb} 2$ node lymphoma cells. Stimulation by 12-O-tetradecanoyl-phorbol-13-acetate. Endocrinology 121 1503-1511.

Too CKL, Vickaryous N, Boudreau RTM \& Sangster SM 2001 Identification and nuclear localization of a novel prolactin and cytokine-responsive carboxypeptidase D. Endocrinology 142 1357-1367.

Turowski P, Fernandez A, Favre B, Lamb NJ \& Hemmings BA 1995 Differential methylation and altered conformation of cytoplasmic and nuclear forms of protein phosphatase $2 \mathrm{~A}$ during cell cycle progression. Journal of Cell Biology 129 397-410.
Vincent V, Goffin V, Rozakis-Adcock M, Mornon JP \& Kelly PA 1997 Identification of cytoplasmic motifs required for short prolactin receptor internalization. Journal of Biological Chemistry 272 $7062-7068$.

Wadzinski BE, Wheat WH, Jaspers S, Peruski LF Jr, Lickteig RL, Johnson GL \& Klemm DJ 1993 Nuclear protein phosphatase 2A dephosphorylates protein kinase A-phosphorylated CREB and regulates CREB transcriptional stimulation. Molecular and Cellular Biology 13 2822-2834.

Wang Y, O'Neal KD \& Yu-Lee L 1997 Multiple prolactin (PRL) receptor cytoplasmic residues and Stat1 mediate PRL signaling to the interferon regulatory factor-1. Molecular Endocrinology 11 1353-1364.

Wells L, Vosseller K \& Hart GW 2001 Glycosylation of nucleocytoplasmic proteins: signal transduction and O-GlcNAc. Science $2912376-2378$.

Woetmann A, Nielsen M, Christensen ST, Brockdorff J, Kaltoft K, Engel AM, Skov S, Brender C, Geisler C, Svejgaard A, Rygaard J, Leick V \& Odum N 1999 Inhibition of protein phosphatase 2A induces serine/threonine phosphorylation, subcellular redistribution, and functional inhibition of STAT3. PNAS 96 10620-10625.

Yu-Lee L 1997 Molecular actions of prolactin in the immune system. Proceedings of the Society for Experimental Biology and Medicine 215 $35-52$.

Received 26 November 2001

Accepted 5 February 2002 